\title{
Zmienność czasowo-przestrzenna występowania trąb powietrznych w Europie i w Polsce w latach 1998-2013
}

\author{
The temporal and spatial variability of the occurrence of tornadoes \\ in Europe and in Poland in the years 1998-2013
}

\section{LUIZA WIECZOREK}

Wydział Nauk Geograficznych, Katedra Meteorologii i Klimatologii, Uniwersytet Łódzki 90-139 Łódź, ul. Narutowicza 88; luiska1991@o2.pl

Zarys treści. Celem pracy jest charakterystyka wystąpień trąb powietrznych w Europie i w Polsce w latach 1998-2013. Zwrócono uwagę na rozkład przestrzenny trąb powietrznych na kontynencie europejskim i na terenie Polski. Przeanalizowano liczbę raportów o trąbach powietrznych w poszczególnych latach, miesiącach, porach roku i porach dnia, dokonano porównania wyników pomiędzy Europą a Polską. Do określenia siły trąb powietrznych użyto skal Fujity oraz Torro. Zbadano zagadnienia: szerokości pasów zniszczeń, kierunków przemieszczania się trąb powietrznych oraz zależności pomiędzy liczbą zgłoszeń trąb powietrznych a ukształtowaniem powierzchni terenu.

Słowa kluczowe: trąba powietrzna, Europa, Polska, skala Fujity, skala Torro, ukształtowanie powierzchni terenu.

\section{Wprowadzenie}

Trąba powietrzna - to wirująca kolumna powietrza będąca w kontakcie z podstawą chmury Cumulonimbus oraz z powierzchnią Ziemi (American Glossary..., 2013; Niedźwiedź, 2003). Ciśnienie w środku wiru spada i przyjmuje on postać leja. W wyniku kondensacji pary wodnej i porwanych z powierzchni cząsteczek kurzu, pyłu, odłamków różnego pochodzenia lej staje się widoczny dla oka ludzkiego (Ahrens, 2001). Lej „Zwisający” z chmury burzowej to zaledwie 10\% całego procesu, jaki wtedy zachodzi (Grazulis, 2003). T. Niedźwiedź (2003) traktuje tornado i trąbę powietrzną jako zjawiska tożsame.

Problematyka trąb powietrznych jest obszernie przedstawiana na łamach literatury zagranicznej. Prekursorem badań tych zjawisk był Alfred Wegener. W 1917 r. podawał, że w Europie rocznie występuje co najmniej 100 trąb powietrznych 
(Davidson, 1996). N. Dotzek (2003) dokonał współczesnej oceny średniej liczby trąb powietrznych w Europie i wyliczył, że rocznie obserwuje się 169 tego rodzaju zjawisk. Te wyniki pokazują, że pomimo unowocześnienia metod badawczych liczba podana przez Wegenera na początku XX wieku była racjonalna. Podsumowanie dotychczasowej wiedzy na temat zjawiska tornadogenezy opublikowali P. Markowski i Y. Richardson (2009). R.A. Muller (2013) szukał odpowiedzi na pytania, czy liczba tornad w ostatnich 58 latach (w Stanach Zjednoczonych) wzrosła z powodu globalnego ocieplenia. Ostatecznie stwierdził, że wzrost liczby zanotowanych tornad ma związek z poprawą jakości obserwacji i nowoczesnych baz danych. Podobne wnioski pojawiły się w pracach dotyczących kontynentu europejskiego (Dotzek, 2003; Groenemeijer i Kühne, 2014; Antonescu i inni, 2016). Charakterystykę czasowo-przestrzenną występowania trąb powietrznych w Europie zawiera opracowanie P. Groenemeijera i T. Kühne (2014). Oprócz trąb powietrznych występujących nad lądem uwzględnili również te, które występowały nad powierzchnią wodną (ang. waterspout). B. Antonescu i inni (2016) opublikowali syntezę wiedzy na temat trąb powietrznych zaobserwowanych w Europie w okresie od 1800 do 2014 r., także w podziale na poszczególne kraje Europy (31).

Liczne artykuły dotyczą zagadnienia intensywności trąb powietrznych (tornad). Najbardziej popularna jest skala Fujity, która służy do określania siły trąby powietrznej na podstawie oceny zniszczeń (Fujita, 1971). C. Doswell i inni (2009) w swojej pracy ocenili potrzebę ulepszenia skali Fujity. Po przedyskutowaniu wielu aspektów ostatecznie stwierdzili, że zmiana skali Fujity (F) na tzw. rozszerzoną skalę Fujity (EF - Enhanced Fujita) jest zasadna, zwłaszcza dla obszaru Stanów Zjednoczonych. Istnieje jednak wiele nowych czynników, które powinny być wzięte pod uwagę i skala powinna być w dalszym ciągu udoskonalana, aby mogła być stosowana na innych kontynentach (Hubrig, 2004; Edwards i inni, 2013).

Liczba polskich opracowań naukowych dotyczących trąb powietrznych nie jest duża. R. Przybylak (2007) opisał podstawowe mechanizmy dotyczące powstawania trąb powietrznych oceniając jednocześnie, że ich występowanie ma związek z ukształtowaniem powierzchni terenu. S. Walczakiewicz i inni (2011) scharakteryzowali warunki synoptyczne sprzyjające występowaniu trąb powietrznych w Polsce w latach 2001-2010. Za najbardziej sprzyjające powstawaniu trąb powietrznych elementy uznali: podwyższone pionowe uskoki wiatru, obniżony poziom kondensacji wymuszonej oraz przechodzenie chłodnych frontów atmosferycznych. Problematyką prognozowania trąb powietrznych zajął się również M. Taszarek (2013). Opisał trzy metody używane w celu prognozowania trąb powietrznych: sondowania atmosferyczne, nowcasting oraz numeryczne modele pogody. W innej pracy M. Taszarek i L. Kolendowicz (2013) podjęli próbę stworzenia uniwersalnego wskaźnika pozwalającego przewidywać trąby powietrzne (ang. Universal Tornadic Index) - przede wszystkim na obszarze centralnej Europy. Wyróżnili dwa główne typy trąb powietrznych: tworzące się w ciepłych warunkach oraz w chłodnych. Czynnikiem decydującym o powstaniu trąby powietrznej 
w ciepłym środowisku jest niestabilność atmosfery. Z kolei w niskiej temperaturze najważniejszym czynnikiem tornadogenezy jest dynamiczne pole wiatru. Wskaźnik UTI można stosować wobec obu rodzajów trąb powietrznych; autorzy przetestowali jego jakość na trąbach powietrznych, które wystąpiły w Polsce w okresie 2008-2010. H. Lorenc (2012) w swojej monografii zawarła rozdział dotyczący trąb powietrznych w Polsce w latach 1998-2010. Podzieliła je na dwa rodzaje: związane ze strefami frontów szkwałowych oraz związane z superkomórkami burzowymi. Analizując poszczególne przypadki posługiwała się obrazami radarowymi oraz satelitarnymi. Obszernej analizy zagadnienia trąb powietrznych w Polsce dokonali M. Taszarek i H.E. Brooks (2015). Charakterystykę zmienności czasowo-przestrzennej trąb powietrznych poprzedzili wnikliwą oceną jakości danych pozyskiwanych za pośrednictwem ESWD (European Severe Weather Database). Badania prowadzili dla dwóch przedziałów czasowych: okresu historycznego (1899-1998) i współczesnego (1999-2013).

Liczne prace przyjmują formę studium przypadku. Jeden z najstarszych dokładnych opisów dotyczy obszaru Lublina - 20.07.1931 r. O sile zjawiska świadczyły fotografie m.in. przewróconych wagonów kolejowych czy pozrywanych dachów, zwłaszcza ze wschodniej dzielnicy Lublina. Skutkiem tej trąby powietrznej były również ofiary śmiertelne oraz kilkanaście rannych osób (Gumiński, 1936). J. Parfiniewicz (2009a, b) przeprowadził dwuczęściową analizę trąby powietrznej w rejonie Częstochowy, 20 lipca 2007 r. Zidentyfikował m.in. obecność polarnego prądu strumieniowego w górnej troposferze, który był jednym z czynników determinujących powstanie trąby powietrznej tego dnia. Innym dokładnie przestudiowanym przypadkiem jest trąba powietrzna, która przeszła nad Podhalem 29.05.2001 r. Na podstawie analizy obrazów satelitarnych oraz fotograficznej i kartograficznej dokumentacji z terenu, określono zasięg zjawiska oraz jego skutki dla środowiska naturalnego Podhala - zwłaszcza obszarów leśnych (Niedźwiedź i inni, 2003). Trąba powietrzna, która wystąpiła w Polsce 15.08.2008 r. stała się przedmiotem badań kilku prac. Autorzy analizowali warunki synoptyczne z tego dnia, dokładny rozwój układu superkomórkowego, który wygenerował opisywaną trąbę powietrzną (Popławska, 2014) oraz skalę uszkodzeń budynków i związane z tym rozwiązania konstrukcyjne, które mogłyby być zastosowane w przyszłości (Chmielewski i inni, 2013).

Celem niniejszego artykułu jest charakterystyka czasowo-przestrzenna wystąpień trąb powietrznych w Europie i w Polsce w latach 1998-2013. Zbadana została liczba trąb powietrznych w Europie i w Polsce w poszczególnych latach, miesiącach i porach dnia. Do analizy siły zjawiska wykorzystano skale Fujity (Fujita, 1971) oraz Torro (Meaden, 1976). Szczególną uwagę poświęcono zagadnieniu szerokości pasów zniszczeń oraz kierunkom przemieszczania się trąb powietrznych. Sprawdzono także zależności pomiędzy liczbą trąb powietrznych a ukształtowaniem powierzchni terenu. 


\section{Baza danych}

Dane na temat liczby trąb powietrznych oraz daty i miejsca ich wystąpienia pochodzą z raportów udostępnianych przez ESSL ${ }^{1}$ w ramach European Severe Weather Database (wersja 4.2.2; http://essl.org/). Raporty poddawane są weryfikacji i otrzymują odpowiednie oznaczenia: QC0 (raporty zgłoszone bez żadnej weryfikacji), QC0+ (raporty wiarygodne, sytuacja meteorologiczna wskazywała na możliwość wystąpienia zjawiska), QC1 (raporty potwierdzone przez wiarygodne źródła: fotografie, materiały filmowe, relacja naocznego świadka) i QC2 (raporty o najwyższej jakości, w pełni zweryfikowane - oparte na dokładnym studium przypadku). Raporty QC0 mogą być zgłoszone przez każdego. W dalszej kolejności, jeśli raport jest błędny zostaje usunięty, jeśli jednak członkowie organizacji: VON (Voluntary Observing Networks; w tym SKYWARN oraz podobne), NHMS (Hydro-meteorological Services) oraz ESSL uznają raport za prawidłowy i wiarygodny dostaje on znakjakości QC0+. Raport QC0+ należy poddać dalszej weryfikacji do poziomu QC1. Znak QC2 mogą nadać tylko członkowie NHMS, rzadko ESSL. Na przestrzeni lat jakość danych ewoluowała. Wraz z rozwojem technologii pojawiły się lepsze i dokładniejsze metody detekcji, a także możliwości rejestrowania niebezpiecznych zjawisk pogodowych, np. za pomocą telefonów komórkowych (Taszarek i Brooks, 2015). Inny problem dotyczy słabej wymiany danych pomiędzy ESWD a niektórymi państwami Europy - może to rzutować na aspekt prezentowanego w bazie danych, przestrzennego zróżnicowania przypadków trąb powietrznych. Pojawiają się również błędy takie jak: wielokrotne wpisanie tego samego zjawiska w kilku raportach, niedokładne określenie miejsca wystąpienia zjawiska oraz czasu jego wystąpienia. Dane pochodzące z raportów są zatem obciążone pewnym ryzykiem błędu. W związku z tym w niniejszej pracy były brane pod uwagę wyłącznie raporty potwierdzone oraz w pełni zweryfikowane dotyczące trąb powietrznych występujących na lądzie. Z ich treści pozyskano szczegółowe informacje o współrzędnych geograficznych miejsc, w których wystąpiły trąby powietrzne, daty oraz godziny występowania, informacje o sile w skali Fujity (Fujita, 1971) i Torro (Meaden, 1976), o kierunku przemieszczania się trąb powietrznych oraz o szerokości pasów zniszczeń (w metrach). Współrzędne geograficzne stały się podstawą do odczytania wysokości nad poziomem morza dla każdej trąby powietrznej. Praca dotyczy okresu 19982013, w którym raporty są lepsze i dokładniejsze niż w latach wcześniejszych. Stworzona na potrzeby niniejszego opracowania baza danych zawiera 1772

\footnotetext{
${ }^{1}$ ESSL - European Severe Storms Laboratory - stowarzyszenie zajmujące się zagadnieniami ekstremalnych zjawisk pogodowych, prowadzące ESWD. Oprócz tego do zadań ESSL należy min. wspieranie i organizowanie europejskich konferencji poświęconych tematyce gwałtownych zjawisk pogodowych (http://www.essl.org/cms/about-us/).
} 
raporty trąb powietrznych, z tego 102 z obszaru Polski. W badanym wieloleciu tylko część raportów zawierała informacje o sile trąb powietrznych (dla Europy w 1019 raportach znalazły się informacje o sile w skali Fujity i 573 raporty z informacją o sile w skali Torro, dla Polski 69 raportów ze skalą Fujity oraz 41 ze skalą Torro). Baza danych o szerokości pasów zniszczeń trąb powietrznych liczy 357 przypadków z obszaru europejskiego oraz 17 z Polski. Informacje o kierunkach przemieszczania się trąb powietrznych dotyczą 394 przypadków, w tym 11 z obszaru Polski. W związku ze specyficznym rodzajem wykorzystywanych danych w niniejszej pracy nie próbowano określać trendów omawianego zjawiska.

\section{Wyniki badań}

\section{Zmienność przestrzenna występowania trąb powietrznych w Polsce i Europie w latach 1998-2013}

W Europie największa koncentracja raportów trąb powietrznych wystąpiła w Niemczech i krajach Beneluksu. Liczne przypadki zgłaszano też w południowo-wschodniej części Wysp Brytyjskich, w zachodniej Francji oraz na Węgrzech. Najmniej trąb powietrznych wystąpiło na Półwyspie Skandynawskim (ryc. 1). W Polsce największa liczba zgłoszeń dotyczyła centrum oraz południa

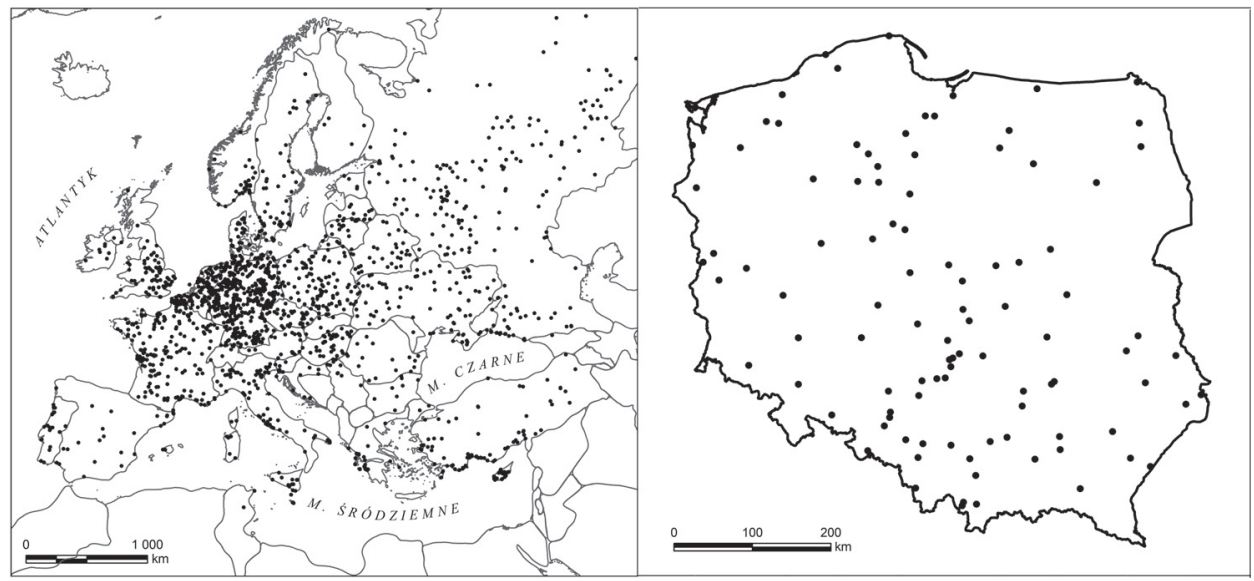

Ryc. 1. Rozkład przestrzenny trąb powietrznych (wg raportów) w Europie* i w Polsce w latach 1998-2013

The spatial distribution of (reported) tornadoes in Europe and in Poland in the years 1998-2013

Opracowanie własne na podstawie ESWD / Author's own elaboration based on ESWD.

* Mapa przestrzennego zróżnicowania zjawiska powstała w ramach podziału świata według WMO-World Meteorological Organization (Europa jako region VI), natomiast we wszystkich innych obliczeniach w niniejszym opracowaniu stosowany był podział polityczny świata, w tym Europy, według https://www.wmo.int/pages/members/region6_en.html. 
kraju. Na tle pasowego układu rzeźby Polski (Kondracki, 2013) podobną liczbę trąb powietrznych zaobserwowano w pasie Pojezierzy (22 raporty), w pasie Nizin (29 raportów) oraz w pasie Wyżyn (27 raportów). Najrzadziej obserwowano trąby powietrzne w obszarach górskich (5) i kotlinach (8), 11 doniesień dotyczyło Pobrzeży Południowobałtyckich (ryc. 1).

\section{Zmienność czasowa}

W badanym okresie w Europie najwięcej raportów trąb powietrznych (161) było w 2013 r., najmniej w 1998 (69) i 2006 (68) (ryc. 2). Liczbę doniesień z roku na rok cechowała duża zmienność. Sposób raportowania zjawisk oraz fakt, że analizowany okres jest zbyt krótki, nie pozwalają określić trendu malejącego bądź rosnącego liczby trąb powietrznych. Można jednak zauważyć pewne okresy wzrostu, przerywane okresami ze znacznymi spadkami liczby zgłaszanych raportów. W Polsce najwięcej raportów pochodziło z 2008 r. - 21, najmniej przypadało na lata: 1998, 2000, 2003, 2006 oraz 2013. W latach 2004 i 2005 w bazie ESWD nie widnieje żaden raport spełniający kryteria niniejszej pracy (status co najmniej QC1, wystąpienie zjawiska nad lądem). Jednak należy zaznaczyć, że w tych latach pojawiły się po dwa niesklasyfi-
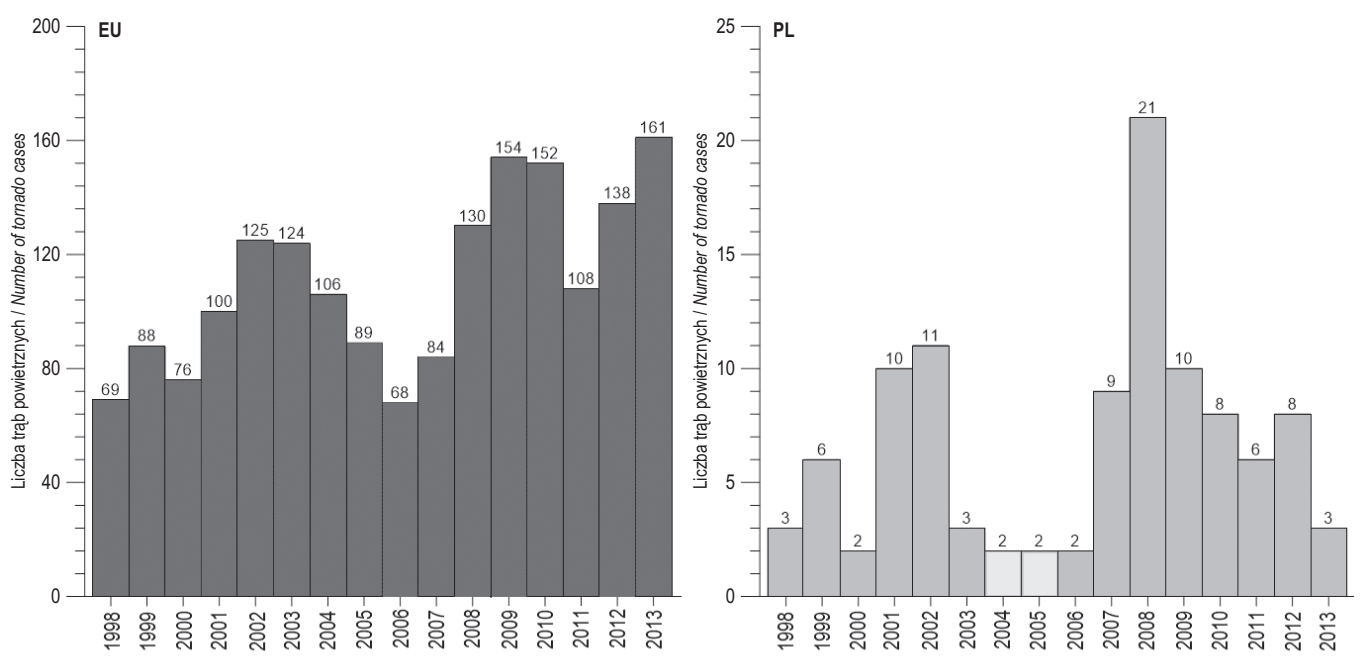

Ryc. 2. Liczba trąb powietrznych (wg raportów) w Europie i w Polsce w poszczególnych latach z okresu 1998-2013

Numbers of (reported) tornadoes in Europe and Poland in particular years of the period 1998-2013

Opracowanie własne, podobnie jak pozostałe wykresy. / Author’s own elaboration, as well as other figures. 
kowane ${ }^{2}$ raporty trąb powietrznych (z dobrze opisanymi: siłą w skali Fujity i Torro oraz szerokością pasa zniszczeń) - rycina 2.

Analizie poddano również średnią liczbę raportów w poszczególnych miesiącach badanego 16-lecia. W Europie najwięcej trąb powietrznych pojawiało się od maja do sierpnia, z największym nasileniem w lipcu - średnio 23. W porze chłodnej średnia liczba raportów o trąbach powietrznych wynosiła od 2,5 do maksymalnie 4,87. Trąby powietrzne najrzadziej pojawiały się w marcu - średnio 2,5 raportu (ryc. 3). W Polsce najwięcej raportów również dotyczy pory ciepłej - od maja do sierpnia. Polskę od Europy odróżniało maksimum średniej liczby raportów, przypadające w Polsce na sierpień - średnio 0,28. Najmniej raportów o trąbach powietrznych z obszaru Polski zgłoszono do ESWD w marcu, kwietniu oraz listopadzie (średnio 0,01 na miesiąc), z grudnia nie pochodzi żaden (ryc. 3). Obydwa wykresy prezentują zmienność roczną: najmniej trąb powietrznych wystąpiło zimą, wiosną ich liczba wzrasta, latem jest najwięcej, a jesienią ponownie mało.

Sporządzono graficzny przebieg liczby raportów trąb powietrznych w Europie i w Polsce $\mathrm{w}$ analizowanym okresie w ujęciu miesięcznym oraz rocznym (ryc. 4). Potwierdził się wniosek, że zarówno w Europie, jak i w Polsce raporty o trąbach powietrznych najczęściej zgłaszano w miesiącach letnich. Wyjąt-
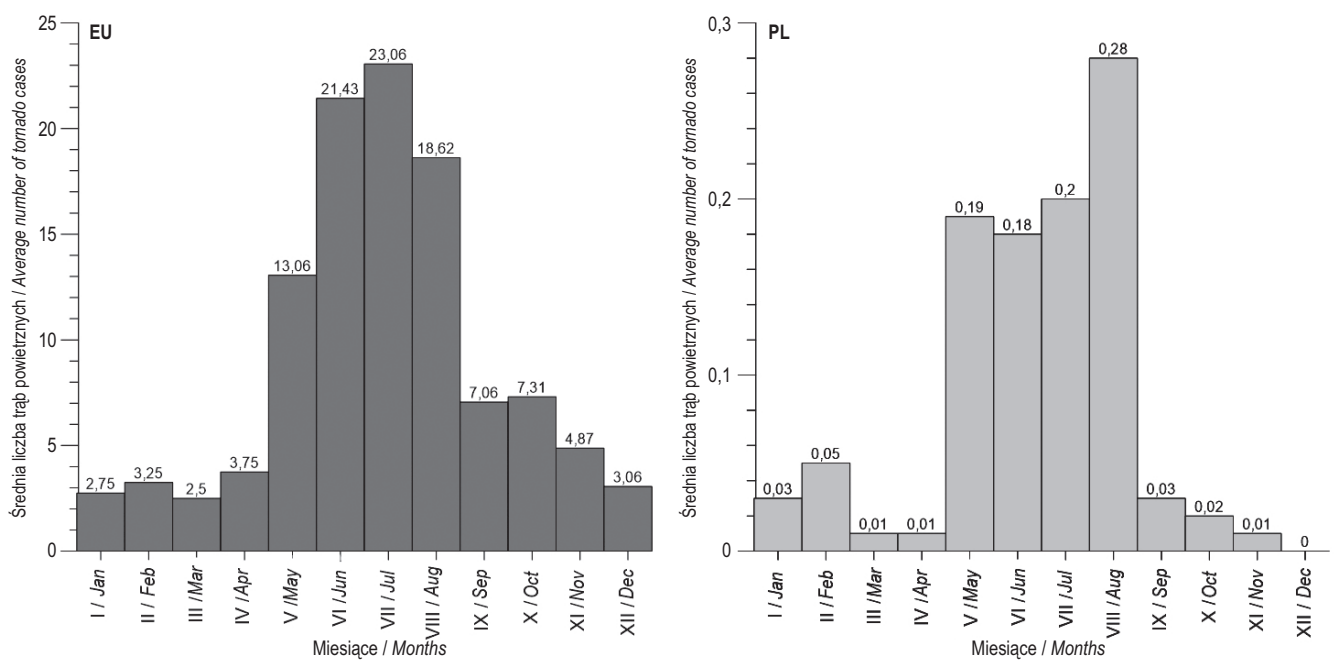

Ryc. 3. Średnia liczba trąb powietrznych w Europie i w Polsce w poszczególnych miesiącach w latach 1998-2013

Average numbers of tornadoes in Europe and in Poland in different months of the 1998-2013 period

\footnotetext{
${ }^{2}$ Trąby powietrzne, których nie zaliczono ani do występujących nad lądem, ani nad zbiornikiem wodnym.
} 
kiem w skali Europy był rok 2006 - z najmniejszą liczbą raportów, a najwięcej doniesień w tym roku dotyczyło okresu wiosennego. Można zauważyć, że sierpień 2008 r. wyróżniał się na tle całego okresu 1998-2013 największą liczbą raportów (ryc. 4).

Zbadano również liczbę trąb powietrznych w poszczególnych porach dnia w analizowanym okresie (ryc. 5). W Europie najwięcej raportów dotyczyło godzin 12:00-14:59 UTC (540) oraz 15:00-17:59 UTC (460). Ponad 300
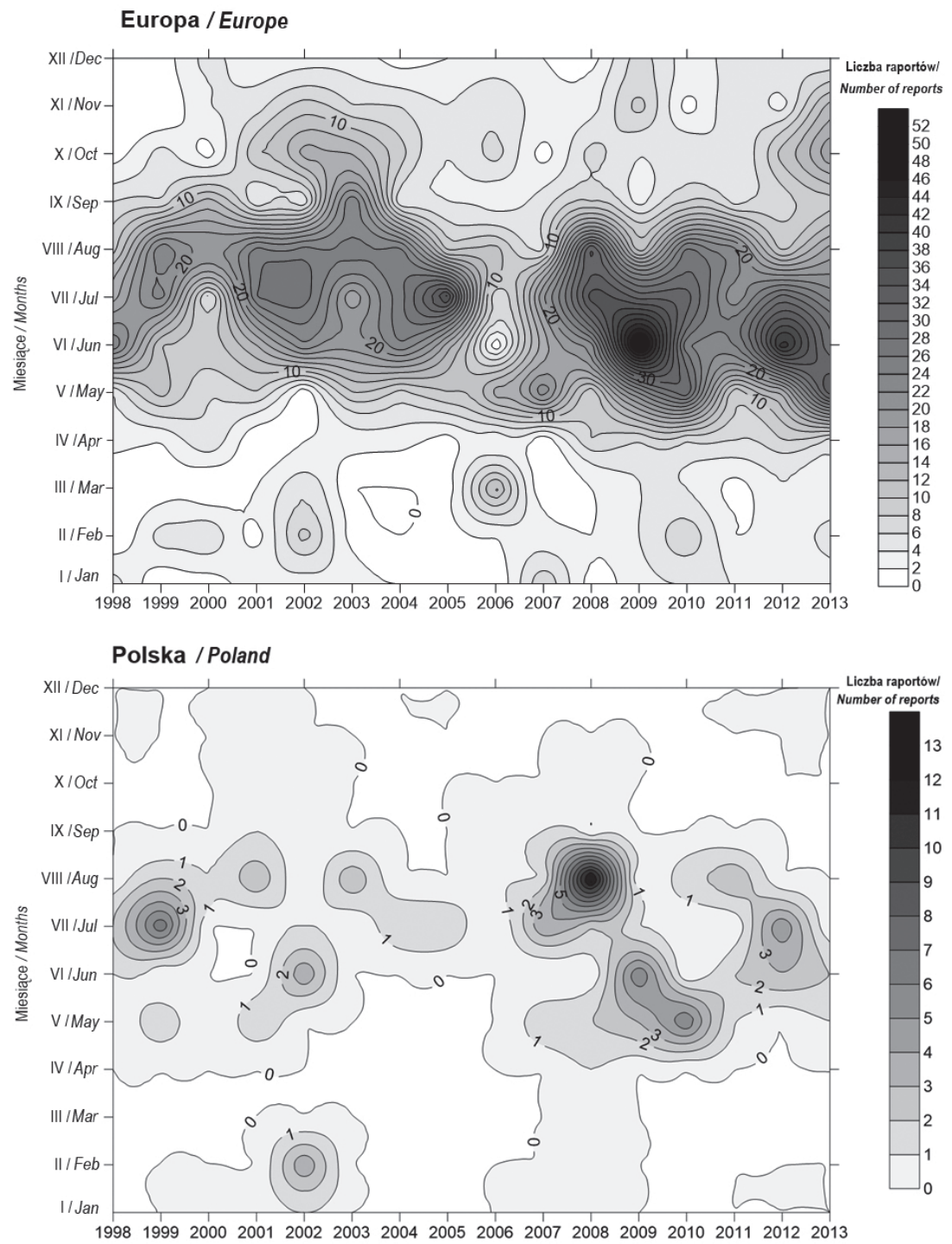

Ryc. 4. Przebieg miesięcznej liczby trąb powietrznych w Europie i w Polsce w latach 1998-2013 Course for monthly tornado totals in Europe and in Poland in the years 1998-2013 
trąb powietrznych w badanym 16-leciu w Europie wystąpiło w godzinach 9:00-11:59 UTC. Wieczorem liczba raportów maleje do około 184 w godzinach 18:00-20:59 UTC oraz $45 \mathrm{w}$ godzinach 21:00-23:59 UTC. W porze nocnej zmieniają się warunki atmosferyczne, zazwyczaj występuje równowaga stała atmosfery, która uniemożliwia rozwój konwekcji. Tworzeniu się trąb powietrznych w godzinach nocnych sprzyjają inne warunki, np. przechodzenie frontu atmosferycznego. W analizowanym okresie w Europie według raportów ESWD w nocy zaobserwowano łącznie 113 trąb powietrznych (godziny 0:00-5:59 UTC). W Polsce najwięcej trąb powietrznych raportowano w godzinach późnopopołudniowych - 43 (15:00-17:59 UTC). Wczesnego popołudnia dotyczyło w Polsce łącznie 26 raportów (12:00-14:59 UTC), najmniej zaś - godzin 3:00-5:59 UTC (1 raport), 6:00-8:59 UTC (2) oraz 21:00-23:59 UTC (3). Porównując wykres dla Europy oraz dla Polski (ryc. 5) zaobserwowano podobną zmienność dobową: $\mathrm{w}$ obu przypadkach trąby powietrzne najczęściej występowały po południu. Z tą różnicą, że w Europie maksimum zgłoszeń przypadało na wczesne popołudnie, a w Polsce na godziny późnopopołudniowe.
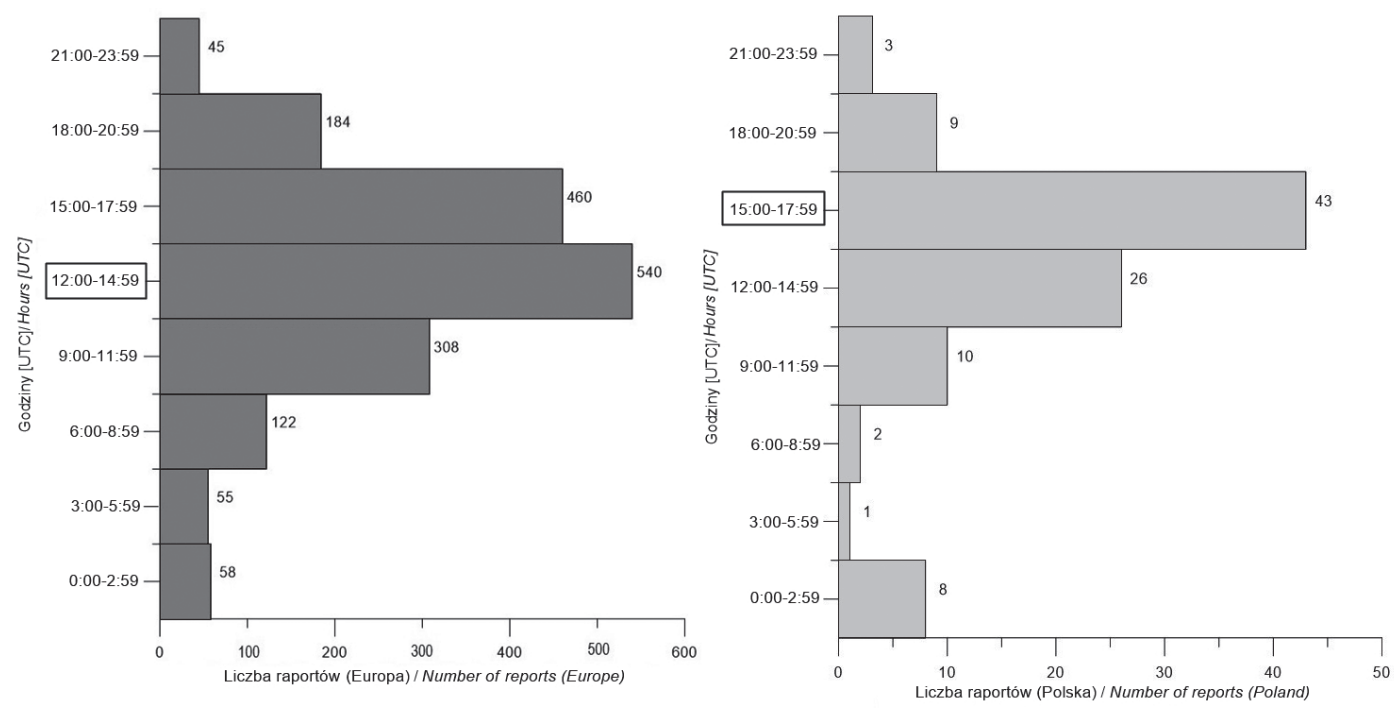

Ryc. 5. Liczba trąb powietrznych w poszczególnych porach dnia w Europie i w Polsce w latach 1998-2013

Numbers of tornadoes at different times of the day in Europe and in Poland in the years 1998-2013 


\section{Siła trąb powietrznych}

W Europie około 1/3 trąb powietrznych osiągała siłę F1 w skali Fujity (117$\left.180 \mathrm{~km} \mathrm{~h}^{-1}\right)$. Raporty z informacją o sile F0 $\left(<117 \mathrm{~km} \mathrm{~h}^{-1}\right)$ stanowiły $13,9 \%$, podobna wartość $-12,9 \%$ - dotyczy trąb powietrznych o sile F2 (181-253 km $\left.\mathrm{h}^{-1}\right)$. Najrzadziej w raportach widnieje siła F3 $\left(254-332 \mathrm{~km} \mathrm{~h}^{-1}\right)-2,5 \%$ i F4 $\left(333-418 \mathrm{~km} \mathrm{~h}^{-1}\right)$ - 0,06\%, a poziom F5 (419-512 $\left.\mathrm{km} \mathrm{h}^{-1}\right) \mathrm{w}$ ogóle się nie pojawił. W Polsce proporcje są trochę inne. Najczęściej odnotowywano trąby powietrzne o sile F1 (31\%) oraz F2 (24\%), a najsłabsze, o sile F0, stanowiły 4\% raportowanych przypadków. Najsilniejszym zjawiskom z bazy ESWD dotyczącym obszaru Polski w analizowanym w niniejszej pracy wieloleciu przypisano siłę F3 (9\%). Jednak późniejsze analizy skali zniszczeń i porównanie wyników z wytycznymi skali Fujity doprowadziły do postawienia nowych hipotez, dotyczących m.in. trąby powietrznej z 15.08.2008 r. Jedna z najsilniejszych trąb powietrznych jakie w ostatnich latach dotknęły obszar Polski przeszła nad województwami: opolskim, śląskim, łódzkim i mazowieckim (Kosin, 2011). Uszkodzenia budynków mieszkalnych i infrastruktury wskazywały, że mogła to być trąba powietrzna nawet o sile F4 w skali Fujity (przykłady miejscowości o największych zniszczeniach: Rusinowice, Balcerzowice) (Chmielewski i inni, 2013; Popławska, 2014). Oprócz wymienionych skutków ta trąba powietrzna wyrządziła ogromne szkody w Parku Krajobrazowym „Lasy nad Górną Liswartą”, położonego w północno-zachodniej części województwa śląskiego (Kosin, 2011).

Skala Torro bazuje wyłącznie na wartościach prędkości wiatru. Tę skalę charakteryzuje większe zróżnicowanie poziomów, zwłaszcza słabszych trąb powietrznych (Meaden, 1976). Odnosząc dane z raportów do skali Torro, w Europie najwięcej trąb powietrznych określono jako przypadki o sile T3 - 148-184 km $\mathrm{h}^{-1}$ (10\%). Niewiele mniejszy procent dotyczył raportów wskazujących na siłę $\mathrm{T} 2$ - 116-147 $\mathrm{km} \mathrm{h}^{-1}, \mathrm{~T} 1$ - 87-115 $\mathrm{km} \mathrm{h}^{-1}$ (po 6\%) oraz T4 - 185-220 km h${ }^{-1}$ (5\%). Raporty informujące o wyższych stopniach skali T7 (300-343 $\left.\mathrm{km} \mathrm{h}^{-1}\right)$ i T8 (343-385 $\mathrm{km} \mathrm{h}^{-1}$ ) nie przekroczyły 1\% w analizowanym 16-leciu. W Polsce również dominowały trąby powietrzne o sile T3 (11\%). Nie było żadnego zgłoszenia o sile trąby powietrznej T0 (61-86 $\left.\mathrm{km} \mathrm{h}^{-1}\right)$, T1 bądź T8. Porównując proporcje, trąby o sile T4, T5 - 221-259 $\mathrm{km} \mathrm{h}^{-1}$ oraz T6 - 260-299 km h${ }^{-1}$ w Polsce obserwowano częściej niż w Europie. Ani w Polsce, ani w Europie w badanym okresie nie pojawiły się raporty o trąbach powietrznych o sile T9 (386-432 $\left.\mathrm{km} \mathrm{h}^{-1}\right)$ i T10 (433-482 $\left.\mathrm{km} \mathrm{h}^{-1}\right)$.

\section{Szerokość ścieżek tornad}

Analiza objęła również szerokość pasów zniszczeń spowodowanych przez trąby powietrzne w Europie w latach 1998-2013. Większość pasów miała szerokość mniejszą niż $100 \mathrm{~m}$ - 72\% (ryc. 6). W największej liczbie raportów (278) jest 
mowa o pasie zniszczeń o szerokości od 51 do 100 m (ryc. 6). Wyróżniały się 4 charakterystyczne szerokości: $100 \mathrm{~m}$ - 43 raporty, $20 \mathrm{~m}$ - 36 oraz $30 \mathrm{~m}$ - 31 raportów. Dość liczne były trąby powietrzne, które zostawiły za sobą pas zniszczeń o szerokości 150 m - 28 i o szerokości 200 m - 21 przypadków. Zaobserwowano dwa tornada o szerokości pasów zniszczeń kolejno 1000 i 2000 m - obydwa na obszarze Polski (ryc. 6).

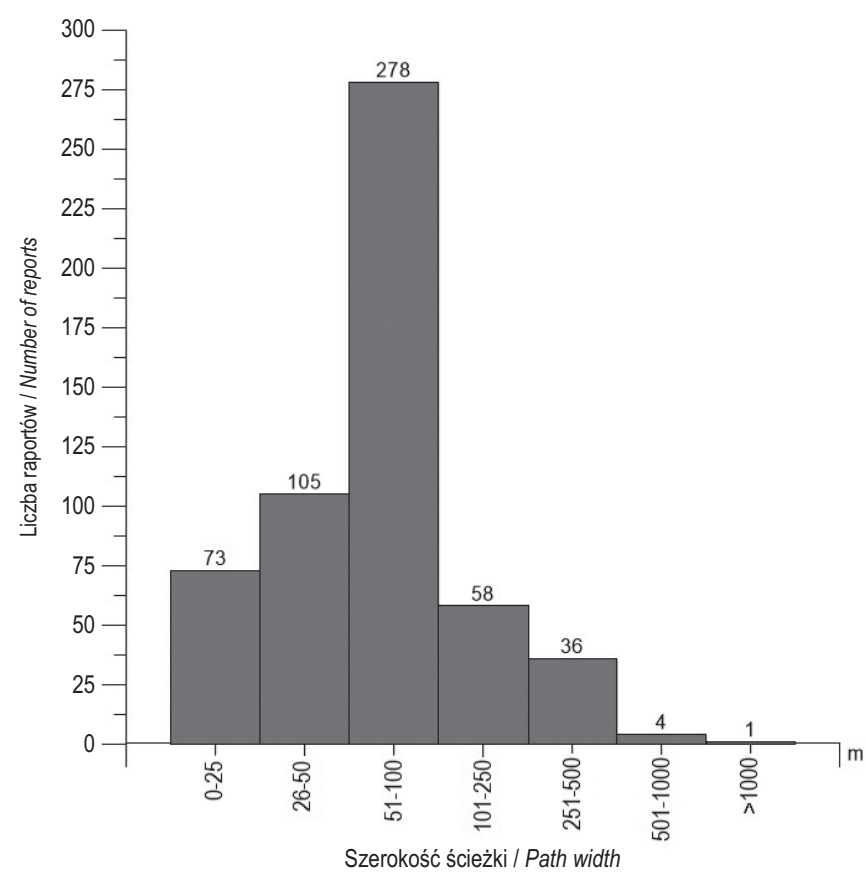

Ryc. 6. Liczba tornad o różnej szerokości pasa zniszczeń w Europie w latach 1998-2013

Number of tornadoes of different path widths occurring in Europe in the years 1998-2013

\section{Kierunki przemieszczania się trąb powietrznych}

W badanych 16 latach w Europie dominowały trąby powietrzne, które przemieszczały się z kierunku południowo-zachodniego i zachodniego w kierunku północno-wschodnim oraz wschodnim (239 przypadków). W Polsce także przeważały trąby powietrzne o kierunku ruchu południowy zachód-północny wschód (10 przypadków). Trzy trąby powietrzne swój bieg zaczęły kolejno: ze wschodu na zachód, ze wschodnio-południowego wschodu na północny zachód oraz z południowego wschodu również na północny zachód. 


\section{Wpływ ukształtowania powierzchni terenu na częstość występowania trąb powietrznych}

Według danych z raportów bazy ESWD w Europie najwięcej trąb powietrznych wystąpiło na obszarach z przedziału wysokości 0-100 m n.p.m. - $46 \%$. 1/4 przypadków dotyczyła wysokości z przedziału 100-200 m n.p.m., a mniej niż po 1\% - przedziałów wysokości: 600-700, 700-800, 800-900, 900-1000 m n.p.m. (ryc. 7). Średnia wysokość miejsc, w których pojawiały się trąby powietrzne na obszarze Europy wyniosła 177 m n.p.m. Ze sporządzonego wykresu odczytano zależność dotyczącą obszaru Europy - wraz ze wzrostem wysokości n.p.m. maleje liczba trąb powietrznych (wykluczono skrajne przedziały: depresje oraz obszary >1000 m n.p.m.) (ryc. 7). Najczęściej trąby powietrzne w Europie pojawiały się w analizowanym 16-leciu na nizinach - 84\%, najrzadziej na obszarach depresji - 1\% (przede wszystkim w Holandii). Według analizowanych raportów trąby powietrzne rzadko tworzyły się na wyżynach - 10\% przypadków oraz obszarach górskich - 6\%. W Polsce najwięcej tornad wystąpiło w miejscach na wysokości 100-200 m n.p.m. - 34\%, najmniej przypadków dotyczyło zaś przedziałów 300400 oraz $>500$ m n.p.m. - po 2\% (ryc. 7). W Polsce, inaczej niż w Europie, nie zauważono spadku liczby trąb powietrznych wraz ze wzrostem wysokości n.p.m. - liczba trąb powietrznych z przedziału wysokości 100-200 m n.p.m. była wręcz o kilka przypadków większa od przedziału 0-100 m n.p.m. (ryc. 7).
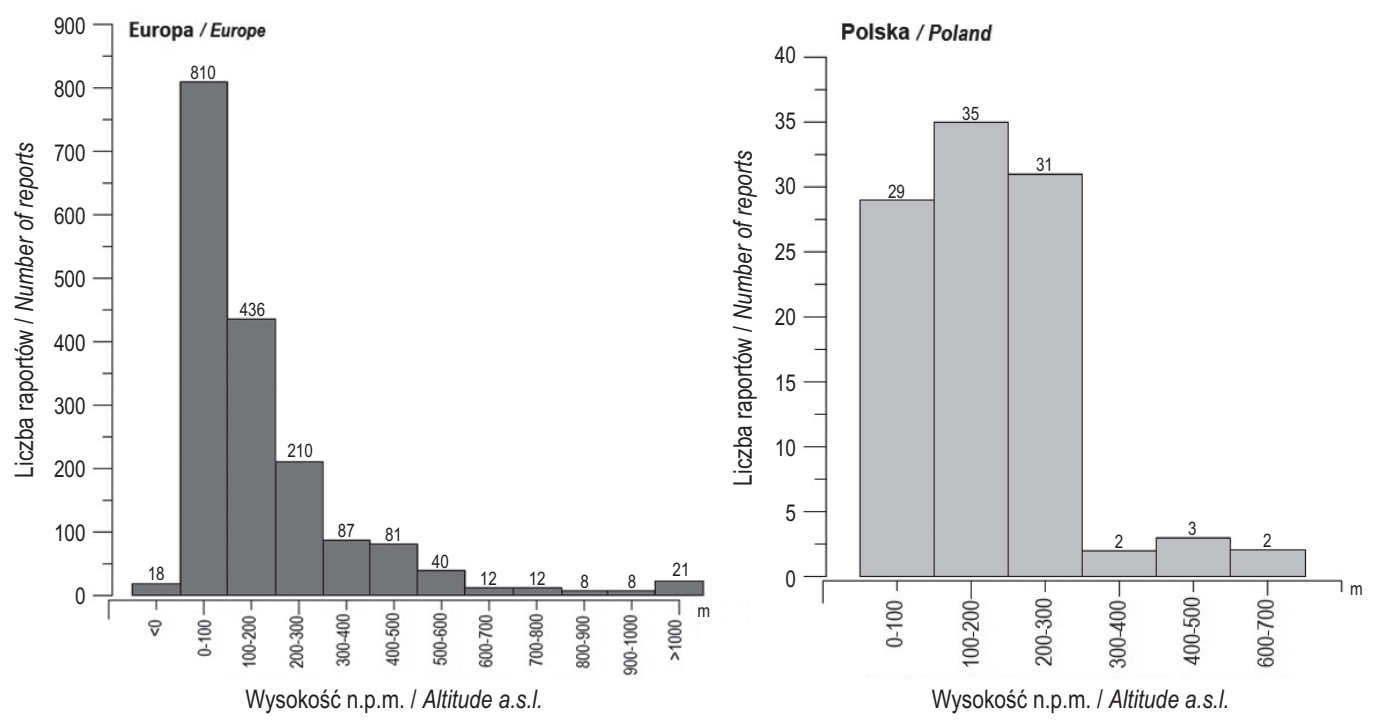

Ryc. 7. Liczba trąb powietrznych na różnych wysokościach n.p.m. w Europie i w Polsce Numbers of tornadoes occurring at different altitudes a.s.l. in Europe and in Poland 


\section{Podsumowanie}

W latach 1998-2013 w Europie według raportów ESWD potwierdzonych i w pełni zweryfikowanych nad lądem wystąpiły 1772 trąby powietrzne, a w Polsce 102. Najwięcej trąb powietrznych zaobserwowano w Niemczech, liczne też w południowo-wschodniej części Wysp Brytyjskich. Te wyniki w większości są zgodne z dotychczasowymi badaniami (Groenemeijer i Kühne, 2014; Taszarek i Brooks, 2015). B. Antonescu i inni (2016) podają, że najwięcej trąb powietrznych na kontynencie europejskim obserwuje się w Europie południowej oraz środkowej. W Polsce można wydzielić charakterystyczny pas, wzdłuż którego prawdopodobieństwo występowania trąb powietrznych jest największe (prawdopodobieństwo w niniejszej pracy liczono według rozkładu Poissona). Pas ma przebieg południkowy: od zachodniej części Podkarpacia, przez Wyżynę Śląsko-Krakowską, Wyżynę Małopolską, centralną część Nizin Środkowopolskich, po wschodnią część Pojezierza Południowobałtyckiego. H. Lorenc (2012) zajmuje odmienne stanowisko podaje, że trąby powietrzne w Polsce najczęściej pojawiają się w pasie od Opola przez Małopolskę, Polskę Środkową, Wyżynę Kutnowską, region Mazowsza do Suwałk. Różnice te są wynikiem zastosowania odmiennych baz danych. Ponadto H. Lorenc (2012) analizowała okres od 1998 do 2005, czyli o 8 lat krótszy niż ujęty w niniejszym artykule. M. Taszarek i H.E. Brooks (2015) w swojej pracy użyli pojęcia „Polska Aleja Tornad” określając jej przebieg od Opola przez obszar Małopolski, aż po Łódź. Autorzy zbadali również rozmieszczenie raportowanych trąb powietrznych o sile $>$ F2. Otrzymane wyniki pokrywają się zaproponowanym przez H. Lorenc (2012) przebiegiem SW-NE - opisanym wyżej. W badanym okresie raporty trąb powietrznych w Europie i w Polsce najczęściej pochodzą z ciepłej pory roku (od maja do sierpnia); identyczne wnioski zawarli w swojej pracy Taszarek i Brooks (2015). W artykule R. Przybylaka (2007) okres występowania największej liczby trąb powietrznych zaczyna się w czerwcu i trwa do sierpnia.

Według analizowanych w opracowaniu raportów ESWD trąby powietrzne na kontynencie europejskim najczęściej tworzyły się po południu, podobnie jak w Stanach Zjednoczonych Ameryki Północnej. Ta wspólna cecha wynika z faktu, że konwekcja zaczyna rozwijać się dopiero w godzinach popołudniowych, gdy grunt wystarczająco się nagrzeje, następnie ogrzeje się od niego warstwa graniczna atmosfery i zainicjowane zostaną ruchy wstępujące. Zdarzają się odstępstwa od tej reguły - poranne trąby powietrzne, bądź występujące w nocy (Przybylak, 2007; Lorenc, 2012; Taszarek i Brooks, 2015). Średnia roczna liczba trąb powietrznych w Europie wynosiła wedle raportów 118. Jest to wynik potwierdzający założenie Wegenera z początku XX wieku. W odniesieniu do średniej, którą podaje N. Dotzek (2003) - około 169 trąb powietrznych rocznie - ta średnia jest dużo niższa.

Jeśli chodzi o siłę, w Europie i w Polsce dominowały trąby powietrzne słabe i umiarkowane, o sile F0, F1 i F2 (w skali Fujity). Podobnie w skali Torro: najczę- 
ściej opisy siły trąb powietrznych wskazywały na początkowe stopnie skali - T0, T1 i T2. W Polsce i Europie dominowały trąby powietrzne o sile T3 (Europa 10\%, Polska 11\% wszystkich raportów).

W Europie szerokość pasów zniszczeń po przejściu trąb powietrznych raczej nie przekraczała $100 \mathrm{~m}$. Dwa raporty informowały o bardzo szerokich pasach zniszczeń: 1000 m i 2000 m - obydwa pochodziły z obszaru Polski (choć tylko niewielka część raportów o trąbach powietrznych w Polsce zawierała informacje o szerokości pasów zniszczeń).

W Europie najczęściej obserwowano sytuacje, w których lej trąby powietrznej po zetknięciu się z powierzchnią ziemi przemieszczał się z kierunku południowo-zachodniego oraz zachodniego (w Polsce głównie ten pierwszy) na północny wschód i wschód.

Rzadko poruszaną do tej pory kwestią (również w Europie) był związek pomiędzy występowaniem trąb powietrznych a ukształtowaniem powierzchni terenu. H. Lorenc (2012) stwierdza, że obniżenia łańcuchów górskich m.in. w rejonie Beskidu Niskiego są miejscem początku formowania się przyszłych trąb powietrznych. W niniejszej pracy zagadnienie wysokości n.p.m. zostało przeanalizowane dla obszaru Europy i osobno dla obszaru Polski. W odniesieniu do Europy określono zależność - wraz ze wzrostem wysokości n.p.m. maleje liczba raportowanych trąb powietrznych. W Polsce większość doniesień dotyczy obszarów o wysokości <300 m n.p.m. Odnosząc to do głównych pasów rzeźby Polski, najwięcej trąb powietrznych odnotowano w Pasie Nizin, następnie niższej części Wyżyn (do 300 m n.p.m.) i w Pasie Pojezierzy. Określenie związku występowania trąb powietrznych z ukształtowaniem powierzchni terenu zasługuje na dalszą, dokładniejszą analizę.

\section{Piśmiennictwo}

Ahrens C. D., 2001, Essentials of Meteorology an Invitation to the Atmosphere, Thomson Brooks/Cole, Chapter 10, Australia.

American Glossary of Meteorology, 2013, http://glossary.ametsoc.org/wiki/Main_Page (25.11.2015).

Antonescu B., Schultz D.M., Lomas F., Kühne T., 2016, Tornadoes in Europe: Synthesis of the observational datasets, Monthly Weather Review, 144, s. 2445-2480.

Chmielewski T., Nowak N., Walkowiak I.K., 2013, Tornado in Poland of August 15, 2008: Results of post-disaster investigation, Journal of Wind Engineering and Industrial Aerodynamics, 118, s. 54-60.

Davidson K., 1996, Twister: The Science of Tornadoes and the Making of a Natural Disaster Movie, Simon and Schuster, New York.

Doswell III C.A., Brooks H.E., Dotzek N., 2009, On the implementation of the enhanced Fujita scale in the USA, Atmospheric Research, 93, s. 554-563.

Dotzek N., 2003, An updated estimate of tornado occurrence in Europe, Atmospheric Research, 67-68, s. 153-161.

Edwards R., LaDue J.G., Ferree J.T., Scharfenberg K., Maier C., Coulbourne W.L., 2013, Tornado Intensity Estimation: Past, Present, and Future, Bulletin of the American Meteorological Society, 94, s. 641-653. 
Fujita T. T., 1971, Proposed characterization of tornadoes and hurricanes by area and intensity, SMRP Research Paper, 91, University of Chicago.

Grazulis T.P., 2003, The Tornado - Nature's Ultimate Windstorm, University of Oklahoma Press Norman, St. Johnsbury.

Groenemeijer P.H., Kühne T., 2014, A climatology of tornadoes in Europe: Results from the European Severe Weather Database, Monthly Weather Review, 142, s. 4775-4790.

Gumiński R., 1936, Trąba powietrzna pod Lublinem w dniu 20 lipca 1931 r., Wiadomości Meteorologiczne i Hydrologiczne, 16, s. 7-9.

Hubrig M., 2004, Analyse von Tornado- und Downburst-Windschäden an Bäumen, Forst und Holz, 59, s. 78-84.

Kondracki J., 2013, Geografia regionalna Polski, Wydawnictwo Naukowe PWN, Warszawa.

Kosin K., 2011, Skutki przejścia trąby powietrznej przez obszar Parku Krajobrazowego „Lasy nad Górna Liswarta” w dniu 15 sierpnia 2008 roku, Acta Geographica Silesiana, 9, WNoZ UŚ-ZPKWŚ, Sosnowiec-Będzin, s. 23-30.

Lorenc H., 2012, Maksymalne prędkości wiatru w Polsce, Instytut Meteorologii i Gospodarki Wodnej, Państwowy Instytut Badawczy, Warszawa.

Markowski P., Richardson Y., 2009, Tornadogenesis: Our current understanding, forecasting considerations, and questions to guide future research, Atmospheric Research, 93, s. 3-10.

Meaden G. T., 1976, Tornadoes in Britain: Their intensities and distribution in space and time, Journal of Meteorology, 1, 8, s. 242-251.

Muller R.A., 2013, The Truth About Tornadoes, The New York Times page A35, http://www. nytimes.com/2013/11/21/opinion/the-truth-about-tornadoes.html? $\mathrm{r}=1$ (29.11.2015).

Niedźwiedź T., German K., Sadowski P., 2003, Synoptic conditions of the tornado occurrence in the Podhale region on 29 May 2001 and its natural and economic impacts, Prace Geograficzne, UJ, 112, s. 55-67.

Parfiniewicz J., 2009a, Tornado w rejonie Częstochowy - 20 lipca 2007 roku. Czesść I: Analiza synoptyczna, Przegląd Geofizyczny, 54, 3-4, s. 147-159.

Parfiniewicz J., 2009b, Tornado w rejonie Częstochowy - 20 lipca 2007 roku. Część II: Symulacje komputerowe i analiza 3D, Przegląd Geofizyczny, 54, 3-4, s. 161-182.

Popławska J., 2014, Tornada superkomórkowe w Polsce - studium przypadku z 15 sierpnia 2008, Prace i Studia Geograficzne, 56, s. 205-229.

Przybylak R., 2007, Traby powietrzne w Polsce, Nowa Era, Biuletyn Internetowy dla Nauczycieli Geografii, 4, s. 1-3.

Stownik meteorologiczny, 2003, red. T. Niedźwiedź, Polskie Towarzystwo Geofizyczne, IMGW, Warszawa.

Taszarek M., 2013, Możliwość prognozowania trąb powietrznych w Polsce, Przegląd Geograficzny, 85, 3, s. 353-371.

Taszarek M., Brooks H.E., 2015, Tornado climatology of Poland, Monthly Weather Review, 143, s. 702-717.

Taszarek M., Kolendowicz L., 2013, Sounding-derived parameters associated with tornado occurrence in Poland and Universal Tornadic Index, Atmospheric Research, 134, s. 186-197.

Walczakiewicz S., Ostrowski K., Surowiecki A., 2011, Warunki synoptyczne wystepowania trąb powietrznych $w$ Polsce $w$ latach 2001-2010, Prace Wydziału Nauk o Ziemi Uniwersytetu Śląskiego, 70, Sosnowiec, s. 43-52.

[Wpłynęło: styczeń; poprawiono: maj 2016 r.] 


\section{LUIZA WIECZOREK}

\section{THE TEMPORAL AND SPATIAL VARIABILITY OF THE OCCURRENCE OF TORNADOES IN EUROPE AND IN POLAND IN THE YEARS 1998-2013}

The aim of the work detailed in this article was to describe instances of tornadoes being reported in Europe and in Poland in the years 1998-2013. According to the relevant ESSWD reports (as confirmed and fully verified), 1772 tornadoes occurred in Europe, while 102 were reported for Poland. The largest number of reports concerned Germany, while numerous cases were also observed for the south-eastern part of the British Isles. These results are consistent with previous studies. Antonescu (2016) reports that most tornado reports in European relate to the continent's northern and central parts. In Poland, it is possible to distinguish a characteristic belt of land along which tornadoes arise most commonly. This runs north-south from the western part of Podkarpacie, through the Silesian-Cracow Upland, the Małopolska Upland and the central part of the Central Polish Lowland, to the eastern part of the South Baltic Lake District. Lorenc (2012) takes a different position over this matter, stating that tornadoes in Poland occur most frequently from the Opole area through the Małopolska region, Central Poland, The Kutno Upland and the region extending from Mazowsze through to the Suwalki region. In the analysed period, tornado reports in Europe and Poland arose most frequently in the summer months (from May through to August). This is in line with the conclusions of Taszarek and Brooks (2015). In turn, Przybylak (2007) states that the period with most tornadoes starts in June and lasts through until August. In Europe, tornadoes are seen to form most often in the afternoon, as is the case in the USA. This common trait stems from the fact that convection only starts developing in the afternoon hours, when the ground is warm enough. This warms the near-ground layer of air and upward movements are initiated. There are exceptions to this rule - morning tornadoes, or even ones occurring at night (Przybylak, 2007; Lorenc, 2012). The average number of tornado reports in Europe amounts to 118 per year, a result in line with the assumptions of Wegener from the early 20th century. However, the present figure is well below the average of some 169 per year given by Dotzek (2003). Where force is concerned, it is weak and moderate tornadoes that dominate in Europe and in Poland, i.e. those of strengths F0, F1 and F2 (on the Fujita scale). A similar situation applies to the Torro scale, with the tornadoes observed most frequently being at the beginning of the scale, i.e. T0, T1 and T2. Poland and Europe experience tornadoes of strength T3 (in 11\% of cases in Europe as whole, and 10\% where Poland is concerned). In Europe there is a prevalence of tornadoes of path width not exceeding $100 \mathrm{~m}$, while the situates observed most frequently are ones in which tornadoes make their landfall and then trek south-west or west (in Poland mostly the south-west direction). Lowlands represent the form of topography most favourable to the occurrence of tornadoes. 